\title{
The Effect of Storage Temperatures on Quality of Minimally Processed Cantaloupe Melon (Cucumis melo L.) with Cassava Starch Based Edible Coating Application
}

\author{
Asri Widyasanti $^{*}$, Sarifah Nurjanah ${ }^{2}$ and Rizika Wulandari ${ }^{3}$, Efri Mardawati ${ }^{4}$ \\ 1,2,3Department of Agricultural and Biosystem Engineering, Faculty of Agro-industrial \\ Technology, Padjadjaran University, Bandung Sumedang km 21 St. Jatinangor, Bandung \\ 4 Department of Agro-industrial Technology, Faculty of Agro-industrial Technology \\ Padjadjaran University, Bandung Sumedang km 21 St., Jatinangor, Bandung
}

Email: asri.widyasanti@unpad.ac.id*

\begin{abstract}
Minimally processed Cantaloupe melon has a short life because it contains high water content which is speeding up the process of spoilage. The objectives of the research were to determine the stearic acid addition on edible coating from cassava starch with low temperature storage to maintain the quality and to extend the minimally processed melon shelf life. This research used a factorial randomized complete design. Edible coating solutions were composed of $3 \%$ cassava starch $(w / v), 1 \%$ carbo methyl cellulose $(w / v)$ and $5 \%$ glycerol $(v / v)$. The treatments consisted of two factors, the first factor was the stearic acid addition on edible coating of 4 levels $10 \%, 0.5 \%$, $1 \%$, and $1.5 \%)$ and the second factor was low temperature storage with 2 levels $\left(5^{\circ} \mathrm{C}\right.$ and $\left.10^{\circ} \mathrm{C}\right)$ with three replications. Observed parameters were respiration rate, moisture content, total titratable acidity, total soluble solids, color and weight loss. Results of this research showed that the best treatment of processed Cantaloupe was the temperature storage of $5^{\circ} \mathrm{C}$ and the $1.5 \%$ stearic acid addition for 5 days storage with respiration rate $33.59 \mathrm{mgCO}_{2} / \mathrm{kg}$ hour; moisture content $8.48 \%$ (d.b.); total titratable acidity 38\%; total soluble solid content 6.17 o brix; Hue angle $88.79^{\circ}$ (yellow); and weight loss $5.85 \%$.
\end{abstract}

Keywords: Cassava starch, Edible coating, Melon, Storage temperature

\section{INTRODUCTION}

Melon (Cucumis melo L.) is a tropical fruit crops grown in Indonesia. One type of melon that is preffered by many local consumers is cantaloupe melon. Cantaloupe melon fruit that consumed in fresh form it takes to peel, seed and slicing disposal. This causes minimal processing of cultivated melon becomes very important.

Minimally processed fruits have a relatively short shelf life due to consist of high water content which accelerates the damage occurred. According to [11], to minimize the spoilage in to a minimum of processed products include storage at low temperatures and the use of layers with an edible coating material. Minimally processed fruit storage is usually carried out at low temperature is in the refrigerator, because it can extend the shelf life. During storage at low temperature, respiratory or metabolic processes in the fruit tissue become blocked.

Natural edible film can be made by starch. The highest starch content presented by cassava. Based on data [1], the national cassava production reached 23.7 million tons. The comparative advantage of cassava 
besides of its high starch content, it is easy to plant and does not cost much. Therefore, production of cassava starch is abundant for food industry applications.

Edible plasticizers should be added when preparing the preparation of the coating solution. According to [9], plasticizers can increase the flexibility and quality of the film, especially if it stored at low temperatures. glycerol is one of plasticizer which commonly used in the edible coating industry. The addition of glycerol will increase flexibility and smoothness of film. Glycerol also can increase the permeability of the film to gases, water vapor, and the solute. To make edible coating become shelf stable, coating solution should be added with emulsifier. According to [7], emulsifiers that can be used to layer edible include Carbo Methyl Cellulose (CMC). In addition, edible layer is hydrophobic material should be added that stearic acid which serves to barrier against water vapor in layers edible [3].

It is necessary to study the effect of storage temperature commodity cantaloupe melon (Cucumis Melo L.) minimally processed layered edible cassava starchbased with the addition of stearic acid.

\section{MATERIAL AND METHODS}

Raw materials used in this study was cassava (cultivar: Manggu Cassava) obtained from Subang plantation. Cantaloupe melon approximately $1.5-2 \mathrm{~kg}$ per fruit, 55 day olds with perfect skin obtained from Madiun Plantations (East Java, Indonesia). Chemicals used were carbo methyl cellulose, glycerol, stearic acid, citric acid, ascorbic acid, distilled water, $\mathrm{Ca}(\mathrm{OH})_{2}, \quad \mathrm{HCl} \quad 0,1 \quad \mathrm{~N}, \quad \mathrm{PP}$ (phenolphthalein), $\mathrm{NaOH} 0,01 \mathrm{~N}, 0,05 \mathrm{~N}$, and $0,1 \mathrm{~N}$. The equipment used were the burette, cold storage, glass beaker, cup, pH meter, viscometer, hot plate stirrer, digital oven, analytical balance, thermo-hygrometer digital, fruit hardness tester, color testing CIE-LAB and hand refractometer.

The laboratory experiments method (experimental laboratory method) is used in this research by using a completely randomized design (CRD) factorial design. The treatment in this study consisted of 2 factors and 3 replications, namely the addition of stearic acid $(a)$ which consists of 4 levels of $0 \%$ : $0.5 \%: 1 \%: 1.5 \%$ and the storage temperature $(b)$ which consists of 2 levels were $5^{\circ} \mathrm{C}$ and $10^{\circ} \mathrm{C}$. Parameters were calculated from the results of this study were respiration rate, moisture content, total titratable acidity, total soluble solids, color and weight loss.

\section{RESULTS AND DISCUSSIONS}

\section{Weight loss}

Measurement of weight loss aimed to calculate the weight changes during storage minimally processed melon. Weight loss at a minimum of cultivated melon largely due to water loss when the process of transpiration.

Figure 1 presented the average weight loss from $6-7 \%$. The value of the weight loss occurred in $1.5 \%$ addition of stearic acid with a storage temperature of $5^{\circ} \mathrm{C}$ was $5.85 \%$. The higher the value the faster the weight loss process of decay melon minimally processed. This is due to the absorption during storage and release of water into the storage environment. According [4], loss of water can affect the loss of weight loss. In addition, the coating gave edible and storage at low temperatures is an effective treatment to maintain a minimum weight of melons processed due to edible layer covering the pores of minimally processed melon can hinder the process of transpiration and respiration so it delays the process of fruit damage. While the melon fruit with minimal processed without coating edible and stored at room temperature (control) had weight loss of high value so that the process of respiration and transpiration increased and melon minimally processed quickly damaged.

Based on the analysis of variance on the addition of stearic acid treatment and storage temperature showed significant effect on weight loss between $2^{\text {nd }}$ to the $4^{\text {th }}$ days storage. From the results of independent testing, the optimum treatment is the treatment of melon minimally 
processed the addition of stearic acid $1.5 \%$ at $5{ }^{\circ} \mathrm{C}$ storage temperature because it has a low value of weight loss compared to the other during storage.

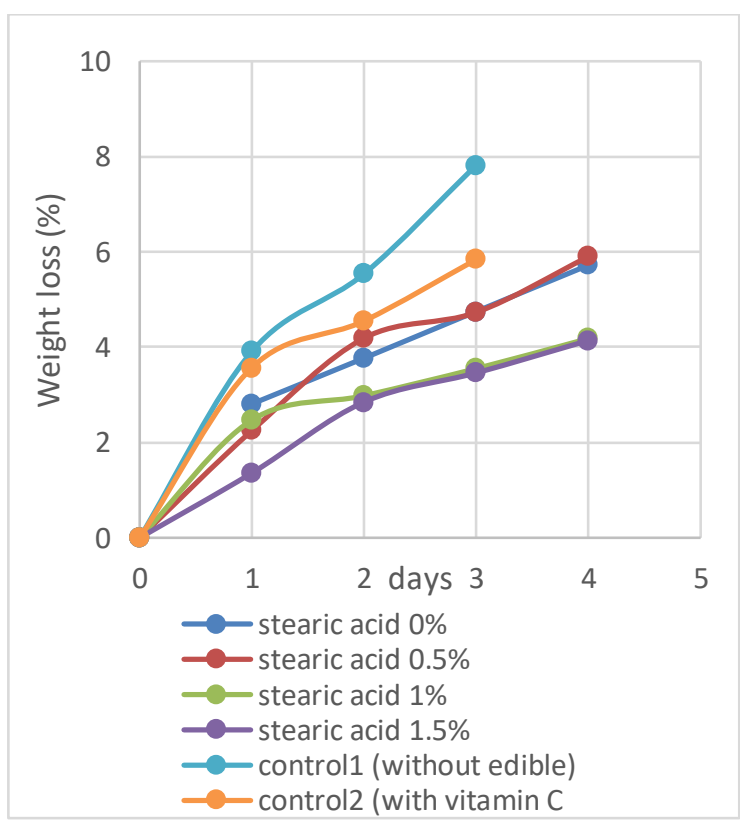

Figure 1. Weight loss of minimally processed Melon under $5^{\circ} \mathrm{C}$ temperature storage

Overall shown in Figure 1 and Figure 2 show that the weight loss increased during storage. The increase in the weight loss melon minimally processed caused by the process of respiration and transpiration during storage resulting in loss of water content. However, compared to the control treatment shrinks more weight and only last until the $2^{\text {nd }}$ day of storage at $5^{\circ} \mathrm{C}$ while the temperature at $10^{\circ} \mathrm{C}$ temperatures last until the 3rd day of storage. The control treatment without edible layer (control 1) and use a layer of vitamin C (control 2) was not able to prevent the evaporation of water from the fruit to the environment through the pores of the fruit that occur during the process of respiration by changing the weight of the sugar so that depreciation has increased. According to [6], the presence of coating on the surface of the fruit causes the process of respiration and transpiration inhibited so that changes in the physico-chemical properties were decline.

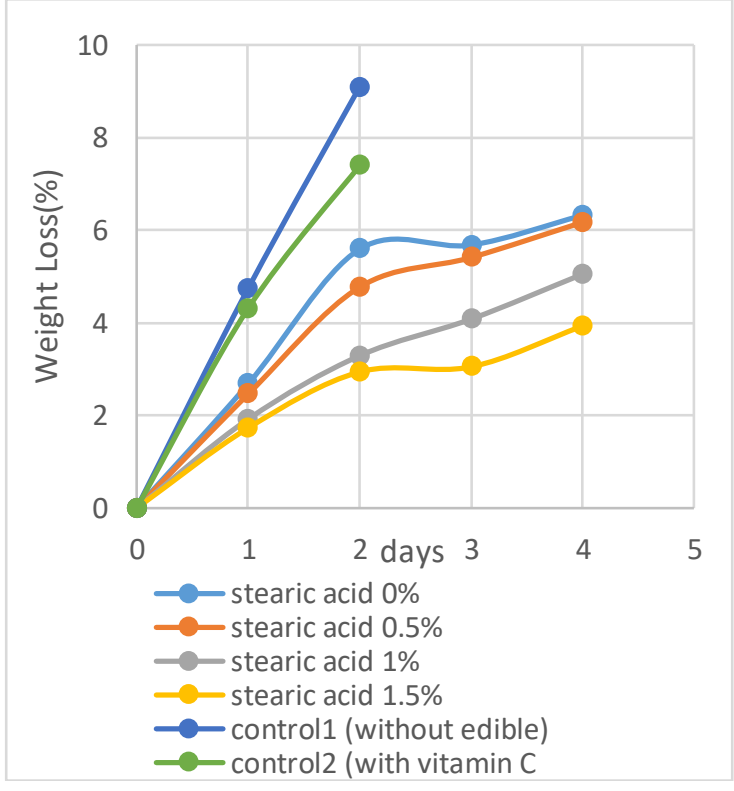

Figure 2. Weight loss of minimally processed Melon under $10^{\circ} \mathrm{C}$ temperature storage

Comparison of minimally processed melon weight loss between low temperature and room temperature proves that the storage at low temperatures can hinder the process of respiration and transpiration. At room temperature storage, the fruit only lasted 1 day of storage. This is due to the control treatment carried out at room temperature, the process that occurs slightly increase transpiration and evaporation of water will have increased so that the water content in the material evaporates higher. As stated by [6] treatment of cold temperatures caused biochemical activity in the fruit inhibited so that the process can be detained fruit damage. Low temperature storage can inhibit the rate of deterioration of fruits because it can reduce the rate of evaporation of water, slowing the rate of a chemical reaction and the rate of microbial growth.

\section{Water Content}

Measurement of water content is one measurement that aims to calculate the percentage of moisture present in the treated melon minimal. This measurement is done every day and using the method of drying or oven (thermogravimetry). 
Overall high water content occurred on addition of stearic acid $1.5 \%$ with a storage temperature of $5{ }^{\circ} \mathrm{C}$. The higher the water content, the lower the value of weight loss melon minimally processed. This was consistent with the results of measurements of weight loss during storage. High water content occurred in $1.5 \%$ addition of stearic acid with a storage temperature of $5{ }^{\circ} \mathrm{C}$ is caused by the addition of a high concentration of stearic acid, the coating is formed with hydrophobic characteristic, it can serve as a barrier against water vapor. These results are in accordance with the opinion [3], that the stearic acid was a saturated fatty acid that has hydrophobic properties and can form a crystalline network with orthorhombic molecular arrangement.

Based on the analysis of variance on the addition of stearic acid treatment and storage temperature showed significant effect on water content on day $2^{\text {nd }}$ to the $4^{\text {th }}$ storage. From the results of independent testing, the optimum treatment was the treatment of melon minimally processed the addition of stearic acid $1.5 \%$ at $5^{\circ} \mathrm{C}$ storage temperature because it has a high water content compared to the other during storage.

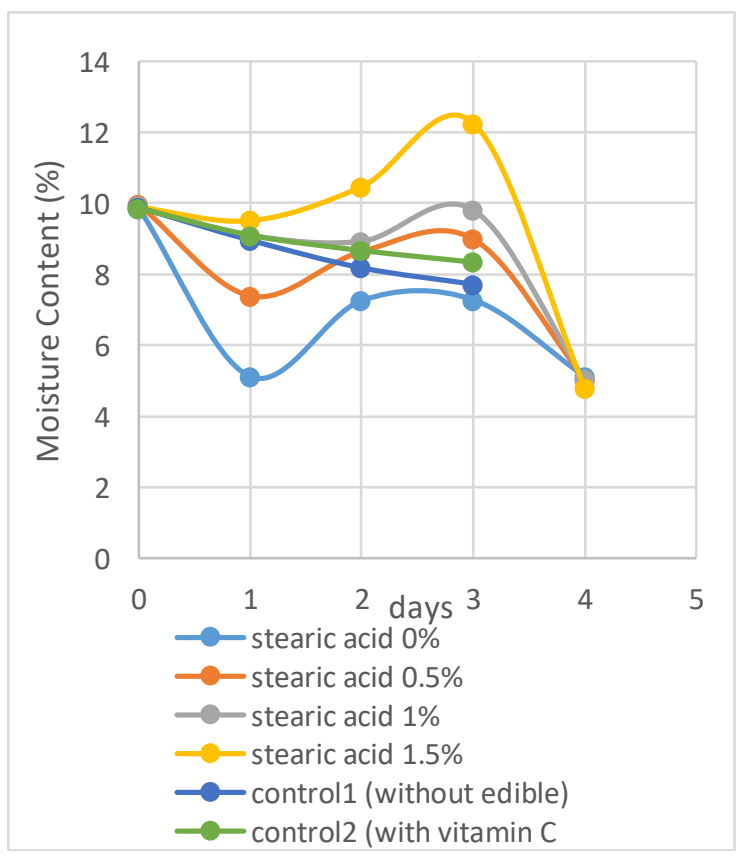

Figure 3. Moisture content of minimally processed Melon under $5^{\circ} \mathrm{C}$ temperature storage
Overall shown in Figure 3 and Figure 4 show that the water content decreased during storage. The decrease of water content in melon minimally processed caused by the evaporation of water from the fruit to the environment during storage resulting in loss of water content. However, compared to the control treatment decreased levels of high water and only last until the $2^{\text {nd }}$ day of storage at $5^{\circ} \mathrm{C}$ while the temperature at $10^{\circ} \mathrm{C}$ temperatures last until the 3rd day of storage. This is due to the control treatment without edible layer (control1) and just use a layer of vitamin $\mathrm{C}$ (control2) are not able to retain $\mathrm{CO}_{2}, \mathrm{O}_{2}$ and water are outgoing or incoming materials so that the process of respiration and transpiration increased.

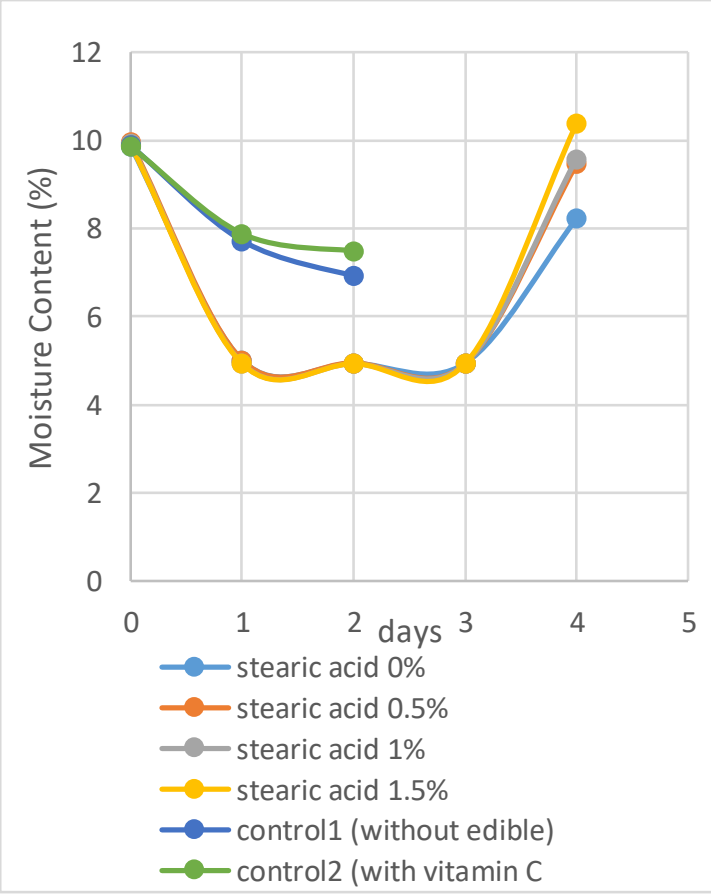

Figure 4. Moisture content of minimally processed Melon under $10^{\circ} \mathrm{C}$ temperature storage

The process of transpiration and respiration leads to reduced water content in the fruit. Transpiration process is lost due to evaporation of water. High evaporation due to the difference in water pressure outside and inside the melon minimally processed. The water pressure in the material is higher than the outside material so that water vapor 
will come out of the material. In respiration occurs burning sugar or substrates that produce $\mathrm{CO}_{2}$, water and energy. Water, gas and energy generated during respiration will undergo evaporation so that the fruit will experience shrinkage weights [8].

Comparison of minimally processed melon water levels between low temperature and room temperature proves that the storage at low temperatures can hinder the process of respiration and transpiration. At room temperature storage, water content decreased and only lasted 1 day of storage. This is due to the control of storage at room temperature resulted in the process of respiration is increased so that the water content in the material evaporates higher than storage at low temperatures. According [2], that in order to minimize water loss in food by means of storage at low temperatures

\section{The Rate of Respiration}

In postharvest physiology, withering and ripening fruit with regard to the nature of the material respiration. Respiration is a process of dismantling the stored organic matter such as carbohydrates, proteins and fats into simple ingredients (sugar) and subsequently oxidized produce energy. The results of this respiration is carbon dioxide $\left(\mathrm{CO}_{2}\right)$, water vapor $\left(\mathrm{H}_{2} \mathrm{O}\right)$ and heat energy.

Based on the analysis of variance for the storage of the addition of stearic acid treatment and storage temperature showed during storage did not make a difference significant effect on the rate of respiration. From each of independent test, where the addition of stearic acid $0 \%$ and storage at 5 ${ }^{\circ} \mathrm{C}$ produces a low respiration rate 33.59 $\mathrm{mgCO}_{2} / \mathrm{kgh}$, while the addition of stearic acid concentration of $1.5 \%$ and storage at a temperature of $10{ }^{\circ} \mathrm{C}$ produce respiration rate values are higher at $85.94 \mathrm{mg} \mathrm{CO}_{2} / \mathrm{kg} \mathrm{h}$. This occurs because stearic acid was a longchain fatty acids. These fatty acids have less oxygen per carbon atom than the sugar that stearic acid requires greater consumption of oxygen to produce $\mathrm{CO}_{2}$. Aerator used when testing the respiration rate of $\mathrm{CO}_{2}$ release oxygen so that the value of $1.5 \%$ stearic acid was slightly higher than others.

Compared with the control treatment without edible layer (control1) and just use a layer of vitamin $C$ (control2) an increase in the rate of respiration and only last until the 2nd day of storage at $5^{\circ} \mathrm{C}$ while the temperature at $10^{\circ} \mathrm{C}$ temperatures last until the $3^{\text {rd }}$ day of storage. This is due to the layer edible able to cover the pores of the melon minimally processed so that it can suppress respiration and transpiration. This was in accordance with [6] which states the presence of a coating on the surface of the fruit causes the process of respiration and transpiration inhibited. Comparison of minimally processed melon respiration rate between low temperature and room temperature storage proves that at low temperatures can hinder the process of respiration.

On the room temperature storage, there was an increased in respiration rate. This was presumably due to storage at low temperatures suppress respiration rate. Values lower respiration rate at $5{ }^{\circ} \mathrm{C}$ storage temperature due to the low temperature chemical reaction rate generally decreased. According [5], that the respiration rate affected by the temperature at which for each $10{ }^{\circ} \mathrm{C}$ increase in temperature, respiration will take place two times greater that indicates that the influence of biological and chemical processes. The process of respiration depends on the storage temperature, where the lower the storage temperature the slower the respiration process also occurs. This corresponds to [4], that the fruit respiration rate strongly influenced by temperature.

\section{Total Soluble Solids}

Measurement of total dissolved solids is one of the measurements as an indicator of the level of a sense of sweetness. Component is the sugar dissolved. The sweeter fruit, the higher the value of total dissolved solids.

Overall the low total dissolved solids occurred on addition of stearic acid 1.5\% with a storage temperature of $5{ }^{\circ} \mathrm{C}$. The higher the value of total dissolved solids, the 
faster the decay process melon minimally processed. The addition of $1.5 \%$ stearic acid causes minimal surface treated better than protected melon and storage at a temperature of $5{ }^{\circ} \mathrm{C}$ support to inhibit the respiration process that triggers the formation of sugar as a substrate to be blocked. According [5], when the process of solving the polysaccharides into simple sugars have been completed, the process of respiration to provide energy that will be used on fruit metabolism continues to cause sugar continuously oxidized. While the melon fruit with minimal processed without coating edible and stored at room temperature (control) has a value of low total dissolved solids so that the process of respiration and transpiration increased and melon minimally processed quickly damaged.

Overall shown in Figure 5 and Figure 6 showed that the total dissolved solids decreased during storage. According to [9], a decrease of total dissolved solids in the treated melon minimum occurs because the sugar formed from the overhaul of starch as a substrate respiration to produce energy. When compared to treatment without edible layer (control1) and only uses layers of vitamin $C$ (control2) has a total value of higher solids. This due to the use of the coating can inhibit the process of respiration so that sugar used as the substrate during the process of respiration reduced. According [10], total dissolved solids indicate the total sugar that occurs as result of the breakdown of carbohydrates, especially starch polymers into sucrose, glucose and fructose.

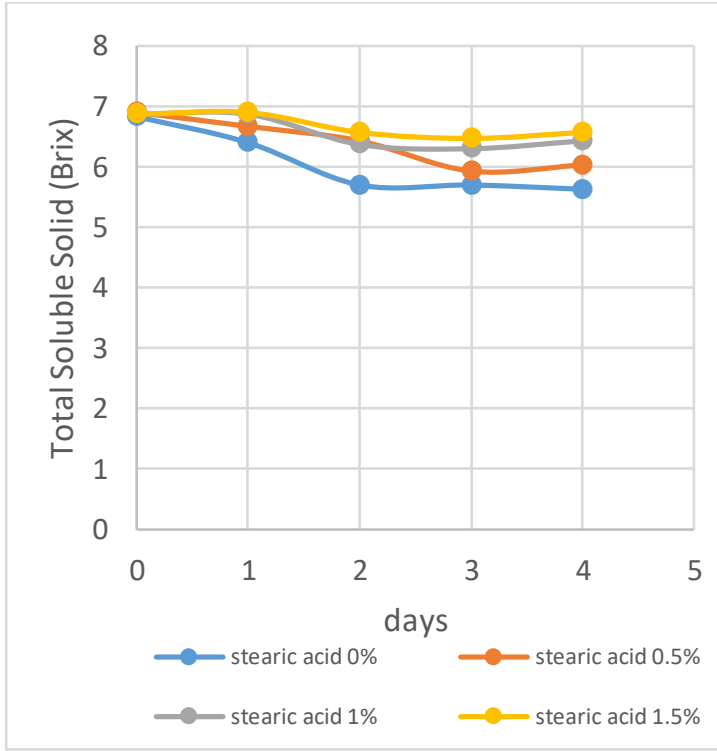

Figure 5. Total Soluble Solid of minimally processed Melon under $5^{\circ} \mathrm{C}$ temperature storage

Comparison of total dissolved solids melon minimally processed between low temperature and room temperature storage proves that at low temperatures can inhibit respiration process to maintain or overhaul transformation of starch into sugar. In the treatment room temperature storage has a total value of high dissolved solids and only lasted 1 day of storage. This is due to the control treatment carried out at room temperature to support the transformation process sugar more quickly. 


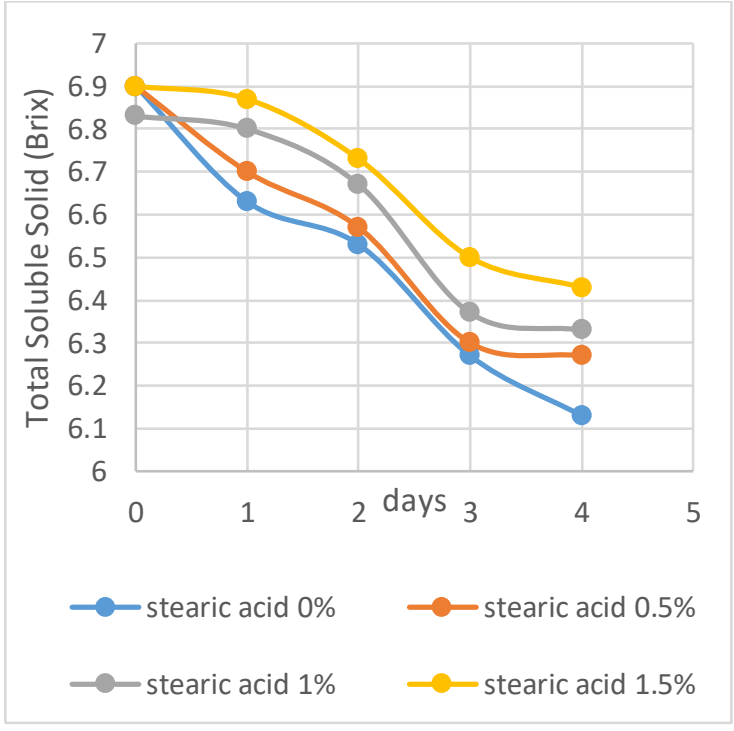

Figure 6. Total Soluble Solid of minimally processed Melon under $10^{\circ} \mathrm{C}$ temperature storage

\section{Color Test}

The role of color is one of the indices of quality of food that needs to be considered because in general the consumer before considering other parameters (taste, nutritional value, etc.) The first would be interested in the color of the material [5]. To perform the analysis of changes in color using CIE-Lab and the obtained values of $\mathrm{L}^{*}$, $a^{*}, b^{*}$. The value of $L^{*}, a^{*}, b^{*}$ in melon minimally processed with taking photos using a camera that has been installed in a black box and then analyzed using Matlab software.

Hue value indicates the color of the melon minimally processed. Hue value is used to classify the flesh color to the specified color range. During storage the Hue undergo changes that can be seen in Figure 7 and Figure 8.

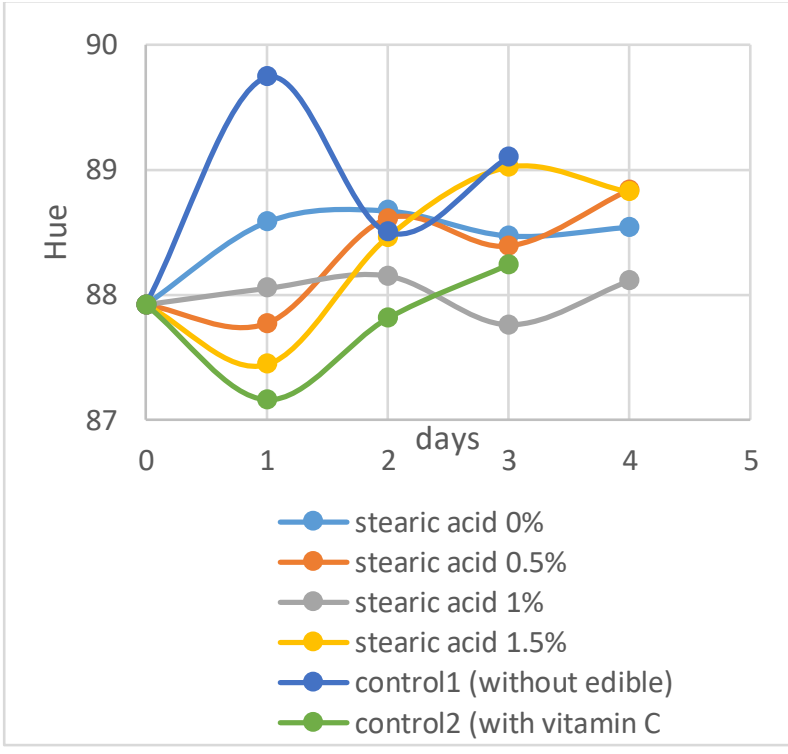

Figure 7. Hue angle of minimally processed Melon under $5^{\circ} \mathrm{C}$ temperature storage

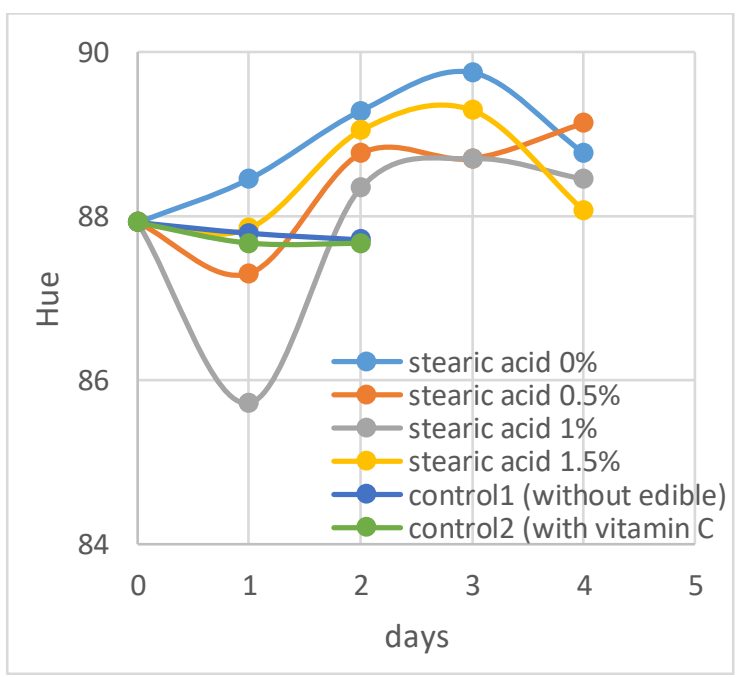

Figure 8. Hue angle of minimally processed Melon under $10^{\circ} \mathrm{C}$ temperature storage

Changes in the value of Hue in Figure 7 and Figure 8 during storage due to the increased influence of moisture content and color pigment degradation by the enzyme was a result of the activities of microorganisms. According [6], a decreased in carotenoid pigment content during storage at low temperatures on fruit. In Figure 8 it can be seen that the value of Hue melon minimally processed control has a smaller value than the use edible layer. During storage, Hue value decreased. This impairment caused by a decrease in the water content, the growth of 
microorganisms is relatively high and the effect of cold temperatures on storage space, causing the degradation of the color pigment. The rate of increase in the value of Hue for low temperature storage of minimally processed melon lower than that of storage at room temperature.

Minimally processed melon fruit color in color chart can be determined from the value of Hue. Based on the color groups according to the value of Hue, discoloration minimally processed melon is classified into groups of yellow color.

\section{Total Titratable Acidity}

Measurement of total titratable acidity aims to measure the acid content pad melon minimally processed. Total acid in this fruit is one of the chemical changes that occur during the storage process

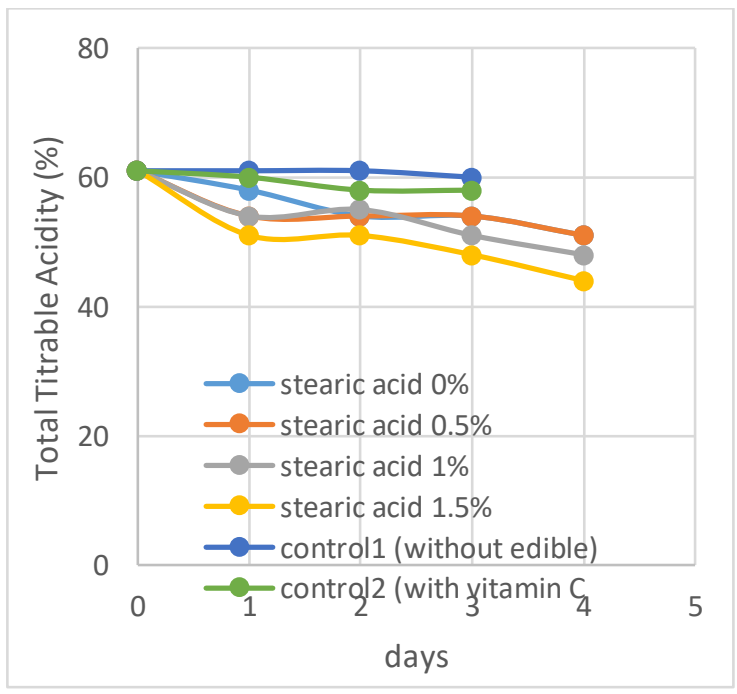

Figure 9. Total titratable acidity of minimally processed Melon under $5^{\circ} \mathrm{C}$ temperature storage

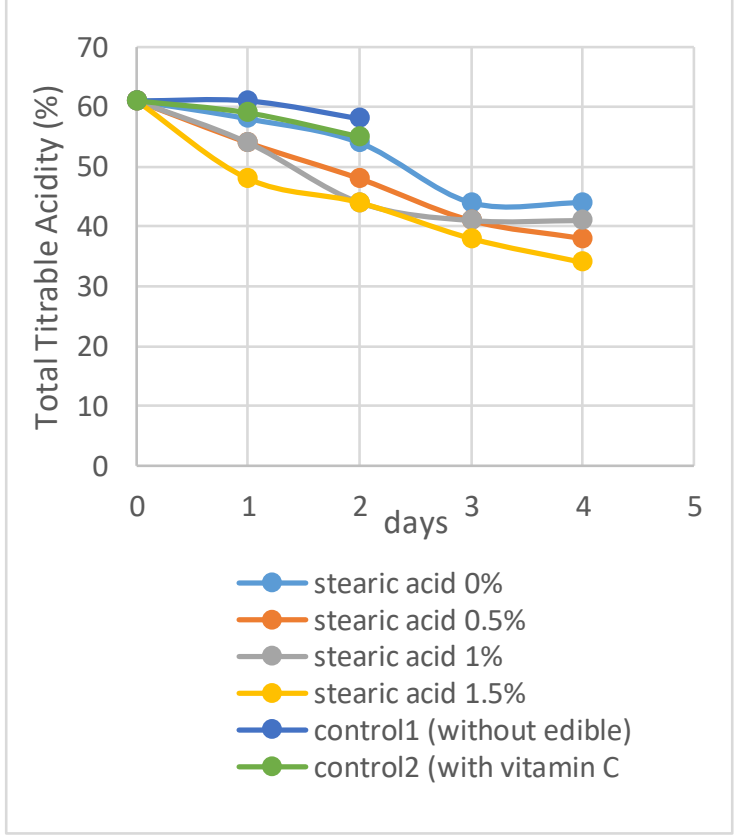

Figure 10. Total titratable acidity of minimally processed Melon under $10^{\circ} \mathrm{C}$ temperature storage

Overall shown in Figure 9 and Figure 10 showed that the total acid decreased during storage. However, compared with the total acid in the control treatment without edible layer (control1) and just use a layer of vitamin C (control2) has a lower value. The high total acid on melons during storage due to decreased levels of organic acids and acid leaching of non-volatile short chain and fatty acids that are volatile. Therefore, melon minimally processed without coating will emit volatile components more than minimally processed melon coated. This brings the total acid in minimal processed melon without coating becomes low. The high acid content in melon coated caused by the accumulation of some volatile components, namely fatty acids of short chain.

Comparison of minimally processed melon total acid between low temperature and room temperature storage proves that at low temperatures can inhibit the decrease in total acid. This due to storage at low temperatures can inhibit respiration process to maintain the total acid content. Total acid content of minimally processed melon tend to decrease during storage. The decline in the 
total amount of acid in the melon caused by acids contained in fruit used as a source of energy for respiration activity of the fruit. The total sugar due to impairment caused by the maturation process of respiration is the process of transforming glucose into simple sugars, followed by the formation of pyruvic acid and other organic acids, aerobically [6]. Acid content is a source of energy for metabolic activity of fruits. Moreover, it can happen conversion of sugars to form acids after passing ripe fruit so that the acid formed during the maturation decreased.

\section{Determination of Best Treatment}

The best treatment of the research can be determined by criteria parameter of the treatment that has the smallest value of weight loss, the largest water content, TAT smallest, biggest Hue value. Based on the results observed parameters best treatment of acid addition stearate and storage temperature used was the addition of stearic acid treated $1.5 \%$ and storage at $5^{\circ} \mathrm{C}$ which has the highest total soluble solid of 6.17 brix; Hue at 88.79 ; TAT by $38 \%$; water content $8.48 \%$ and weight loss of $5.85 \%$.

\section{CONCLUSIONS}

The concentration of stearic acid concentration of $1.5 \%$ was the optimal addition to the starch-based edible coating of cassava that used for minimally processed melon.

Storage at $5^{\circ} \mathrm{C}$ for a minimum of processed cantaloupe melon with edible coating applications with the addition of $1.5 \%$ stearic acid is able to extend the shelf life of up to 5 days compared with no edible coating layer.

The process of edible coating with the addition of stearic acid concentration of $1.5 \%$ was able to keep the quality of minimally processed melon during storage.

Shelf life of melon minimally processed and layered edible with a storage temperature of $5{ }^{\circ} \mathrm{C}$ for up to 5 days, if the storage temperature of $10^{\circ} \mathrm{C}$ the shelf life of product decrease to 4 days.

\section{REFERENCES}

[1] Badan Pusat Statistik. 2012. Produksi Tanaman Sayuran dan Buahbuahan di Indonesia 2012. Badan Pusat Statistik. Jakarta.

[2] Desrosier, N. W. 1988. Teknologi Pengawetan Pangan (Terjemahan M. Muljohardjo dari The Technology of Food Preservation). UI Press. Jakarta.

[3] Fennema, O.R. 1985. Food Chemistry. Marcel Dekker, Inc. New York.

[4] Kader, A.A. 1999. Carambola (Star fruit). Produce Facts. Perishable Handling Quarterly UC. Davis, No. 93, Davis CA, pp 19-20.

[5] Muchtadi, T.R. 1997. Teknologi Proses Pengolahan Pangan. PAU-IPB. Bogor.

[6] Pantastico, E. B. 1989. Fisiologi Pasca Panen Penerjemah; Kamariyani, editor. Yogyakarta: Gajah Mada University Press. Terjemahan dari: Postharvest Physiology, Handling and Utilization of Tropical Fruits and Vegetables.

[7] Rovedo and Singh. 2001. An edible coating to improve the bowl life of ready-to-eat cereals.(http://www.confex.co $\underline{\mathrm{m} / \mathrm{ift} / 99 \mathrm{anual} / \mathrm{abstract} / 3838 \mathrm{~h}}$ tm. . Di akses 11 Januari 2014)

[8] Wills, R. H., T.H. Lee., W.B. Graham, Glasson and E.G. Hall. 1981. Post-harvest, an Introduction to The Physiology and Handling of Fruit and Vegetables. South China Printing Co. Hong Kong.

[9] Winarno, F.G. 2002. Kimia Pangan Dan Gizi. Gramedia. Jakarta.

[10] Wirakartakusumah, M. A., Hermanianto, D, dan Andarwulan, N. 1989. Prinsip Teknik Pangan. PAU-IPB: Bogor.

[11] Wong, D.W.S., Camirand, W.M. and Pavlath, A.E. 1994. Development 
of Edible Coatings for Minimally

Processed Fruits and vegetables.

In: Edible Coatings and Films to

Improve Food Quality. Krochta,

J.M., E.A. Baldwin and M.O.

Nisperos-Carriedo (Eds).

Techonomic Pub. Co., Inc.

Pennsylvania. USA. 